\title{
PENGARUH PERSEPSI HARGA DAN KUALITAS PRODUK TERHADAP KEPUTUSAN PEMBELIAN KONSUMEN YANG DIMEDIASI KEPUASAN KONSUMEN
}

\author{
Ratlan Pardede \\ Magister Manajemen, Universitas Bunda Mulia \\ Alamat surel : rpardede@bundamulia.ac.id \\ Tarcicius Yudi Haryadi \\ Alumni Magister Manajemen, Universitas Bunda Mulia \\ Alamat surel: tarsi_072@yahoo.co.id
}

\begin{abstract}
This study aims to determine the influence of the perception of price and product quality on consumer purchasing decisions which is mediated by satisfaction on Indomaret mini market Rorotan North Jakarta. Indomaret mini market is engaged in the retail sale of goods which needs to pay attention to the behavior of consumers to make decisions.This research is a quantitative survey approach that seeks to know how the influence of the perception of price and product quality on consumer purchasing decisions with customer satisfaction as an intervening variable. Data collection techniques are by using questionaire. The test instrument is used for testing the validity and reliability. As for the technique of data analysis, SEM is used. The study concludes : 1) price perception has a positive and significant effect on customer satisfaction, 2)price perception has not positive and significant effect on consumer purchasing decisions, 3) product quality has a positive and significant effect on customer satisfaction, 4) product quality has not positive and significant effect on consumer purchasing decisions, 5). consumer satisfaction has a positive and significant effect on consumer purchasing decisions, 6). Consumer satisfaction has effect on consumer purchasing decision to mediate price perception and product quality.
\end{abstract}

Keywords: price, product, consumer satisfaction, consumer purchasing

\begin{abstract}
Abstrak
Penelitian ini bertujuan untuk mengetahui bagaimana pengaruh persepsi harga dan kualits produk terhadap keputusan pembelian konsumen yang dimediasi kepuasan konsumen di mini market Indomaret di wilayah Kelurahan Rorotan Cilincing Jakarta Utara. Indomaret merupakan mini market eceran yang bergerak dalam jual beli barang yang perlu memperhatikan perilaku konsumen untuk mengambil keputusan. Penelitian ini merupakan penelitian kuantitatif dengan pendekatan survey yang berusaha untuk mengetahui bagaimana pengaruh persepsi harga dan kualits produk terhadap keputusan pembelian konsumen dengan kepuasan konsumen sebagai variabel intervening. Teknik pengumpulan data yaitu dengan metode kuesioner. Untuk pengujian instrumen menggunakan uji kesahihan dan keandalan. Teknik analisis data menggunakan metode SEM. Adapun hasil dari penelitian adalah : 1). Persepsi harga berpengaruh secara positif dan signifikan terhadap kepuasan konsumen, 2). Persepsi harga tidak berpengaruh secara positif dan signifikan terhadap keputusan pembelian konsumen, 3). Kualitas produk berpengaruh secara positif dan signifikan terhadap kepuasan konsumen, 4). Kualitas produk tidak berpengaruh secara positif dan signifikan terhadap keputusan pembelian konsumen, 5). Kepuasan konsumen berpengaruh secara positif dan signifikan terhadap keputusan pembelian konsumen, 6). Kepuasan konsumen mempunyai pengaruh terhadap keputusan pembelian yang memediasi persepsi harga dan kualitas produk.
\end{abstract}

Kata kunci: harga, produk, kepuasan konsumen, pembelian konsumen

\section{PENDAHULUAN}

\section{Latar Belakang}

Persepsi konsumen pada dasarnya dipengaruhi oleh rangsangan fisik yang berhubungan dengan lingkungan sekitar dan keadaan individu yang bersangkutan. Dengan mengetahui perilaku konsumen dari persepsi yang muncul, perusahaan dapat mengetahui strategi selanjutnya yang akan diambil agar kepuasan konsumen selalu dapat terpenuhi, pada akhirnya konsumen 
yang puas akan menyebarkan getok tular yang positif sehingga akan menimbulkan dampak yang baik bagi perusahaan.

Persaingan bisnis ritel berada dalam lingkup industri dan individual. Keragaman jenis bisnis ritel juga membawa implikasi adanya persaingan pada jenis ritel yang sama dan pada sesama bisnis ritel dari kelas yang berbeda. Penelitian mengenai persaingan bisnis ritel, menyatakan bahwa persaingan dalam industri ritel yang ada di Jakarta dapat diamati dari berbagai segi, yaitu persaingan antara ritel modern dan tradisional, persaingan antara sesama ritel modern, persaingan antara sesama ritel tradisional, dan persaingan antara pemasok (Tambunan, 2004). Persaingan antara ritel modern dan ritel tradisional semakin tidak seimbang dengan adanya jam buka ritel modern (terutama mini market) hingga 24 jam. Kelebihan lain ritel modern adalah kondisi nyaman, kebersihan yang terjaga, berkesan elit, pelayanan bagus, dan barang-barang yang dijual murah, lengkap dan berkualitas. Persaingan bisnis ritel berikutnya terjadi antara sesama perusahaan ritel modern, baik dalam kategori yang sama maupun yang sifatnya tidak langsung karena dalam kategori yang berbeda.
Persaingan pada kelas mini market bisa dilihat dari strategi dan ekspansi yang dilakukan pihak Indomaret, Alfamart, Circle $\mathrm{K}$, Ceria Mart. Bentuk persaingan yang terjadi antara mini market dalam hal perebutan segmen pasar, sistem pelayanan, persaingan harga, dan kualitas produk. Mini market menyediakan berbagai macam kebutuhan yang diperlukan oleh konsumen seperti : rokok, mie instan, minyak goreng, barang-barang toiletries, alat kecantikan, susu bubuk dan kental manis, aneka biskuit dan roti basah, minuman ringan bersoda atau tidak bersoda dengan kemasan yang beraneka (kotak, kaleng dan botol), perlengkapan rumah tangga, bahan kue, pembasmi serangga, obat-obatan bebas, alat listrik alat tulis, perlengkapan baby dan juga terkadang tersedia mainan anak-anak,

Indomaret merupakan salah satu mini market yang tumbuh dan berkembang di wilayah Rorotan, Cilincing Jakarta Utara. Mini market ini memiliki market dan konsumen dengan berbagai kalangan, mulai dari kalangan anak-anak sampai orang dewasa, ini disebabkan karena Indomaret menyediakan berbagai macam keperluan konsumen atau pelanggan. Data penjualan Indomaret disajikan pada Tabel 1. berikut :

Tabel 1. Data Penjualan Indomaret

Sumber : Indomaret, 2015

\begin{tabular}{|l|l|r|}
\hline No & \multicolumn{1}{|c|}{ Bulan } & Jumlah Penjualan (Rp.) \\
\hline 1 & Agustus 2014 & 10.300 .150 \\
\hline 2 & September 2014 & 10.040 .420 \\
\hline 3 & Oktober 2014 & 9.866 .470 \\
\hline 4 & Nopember 2014 & 9.359 .900 \\
\hline 5 & Desember 2014 & 8.600 .720 \\
\hline 6 & Januari 2015 & 8.351 .470 \\
\hline 7 & Februari 2015 & 8.254 .440 \\
\hline 8 & Maret 2015 & 7.912 .630 \\
\hline 9 & April 2015 & 7.196 .410 \\
\hline
\end{tabular}

Berdasarkan Tabel 1, total penjualan Indomaret mengalami penurunan mulai dari bulan Agustus 2014 hingga bulan April 2015. Menurut pihak manajemen Indomaret, hal ini disebabkan oleh beberapa faktor antara lain : musim hujan, liburan, kenaikan harga (terlebih pada tahun 2015 harga sebagian besar naik) karena menguatnya nilai mata uang dollar terhadap rupiah, para pesaing Indomaret yaitu Alfamart dan Ceriamart mampu menjual produknya dengan relatif lebih murah, terlebih Alfamart dengan kartu AKU akan lebih murah 5\% dari harga biasa. Sebagai bentuk pelayanan kepada masyarakat Indomaret, selain menjual produk makanan dan minuman, 
keperluan rumah tangga, juga menjual produk pelayanan, seperti pembayaran token listrik, angsuran kredit melalui kerja sama dengan perusahaan pembiayaan, yaitu ADIRA, FIF, WOM, dan yang terbaru adalah para konsumen dapat membayar iuran/asuransi BPJS kesehatan. Pada harihari tertentu Indomaret mengadakan program discount ataupun beli satu gratis satu untuk jenis produk tertentu. Program ini bertujuan untuk menarik calon konsumen untuk berbelanja di Indomaret.

Kotler dan Armstrong (2001) mengemukakan bahwa harga adalah sebagai jumlah uang yang dibebankan atas suatu produk atau jasa. Menurut Tjiptono (2004) menyatakan bahwa harga merupakan satuan moneter atau ukuran lainnya (termasuk barang atau jasa lainnya) yang ditukarkan agar memperoleh hak atas penggunaan suatu barang. Harga merupakan salah satu faktor penting dalam penjualan. Banyak perusahaan bangkrut karena mematok harga yang tidak cocok di pasar. Harga yang ditetapkan harus sesuai dengan perekonomian konsumen, agar konsumen dapat membeli barang tersebut, sedangkan bagi konsumen harga merupakan bahan pertimbangan dalam mengambil keputusan pembelian karena harga suatu produk memengaruhi persepsi konsumen mengenai produk tersebut. Nadia et al. (2014) menyatakan bahwa persepsi harga berpengaruh positif dan signifikan terhadap kepuasan pelanggan.

Ditinjau dari kualitas produk yang dijual Indomaret sama dengan para pesaingnya. Produk yang dijual berasal dari perusahaan ternama dan sudah teruji kualitasnya. Perbedaan dari para pesaingnya terutama Alfamart, adalah bahwa Indomaret bukan hanya menjual produk keperluan sehari-hari, tetapi juga menjual produk pelayanan pembayaran, dan produk yang ada merupakan produk yang berkualitas serta sudah dikenal di masyarakat. Kualitas produk merupakan salah satu faktor yang kurang diperhatikan oleh perusahaan, sehingga konsumen akan berpikir lagi untuk menggunakan produk tersebut dan akan merasa tidak puas setelah membeli atau menggunakan barang atau jasa tersebut.
Perusahaan yang bertahan di era persaingan global seperti saat ini juga harus memperhatikan manfaat yang diperoleh konsumen setelah membeli atau menggunakan barang atau jasa tersebut, sebab hal tersebut merupakan salah satu faktor untuk mengkaji tentang kepuasan konsumen. Keunggulan manfaat yang diberikan mengakibatkan pada akhirnya untuk kesempatan mendatang akan melakukan pembelian ulang ataupun memberikan rekomendasi kepada orang lain untuk melakukan pembelian (Rangkuti, 2006). Kualitas produk memiliki dampak langsung pada kinerja produk, oleh karena itu kualitas berhubungan erat dengan nilai dan keputusan pembelian dari konsumen, dalam arti sempit kualitas bisa didefinisikan sebagai "bebas dari kerusakan", kualitas berarti kemampuan produk untuk melaksanakan fungsinya; termasuk keawetan, keandalan, ketepatan, kemudahan dipergunakan dan diperbaiki. Kualitas harus diukur dari segi persepsi atau tanggapan dari pembeli, kualitas merupakan peluang untuk bersaing (Kotler,2006). Hasil penelitian Lonardo et al. (2014) menyatakan bahwa kualitas produk mempunyai pengaruh terbesar bagi kepuasan konsumen, setelah harga. Demikian juga Suci Widyawati et al. (2012) menyatakan bahwa kualitas produk, harga, dan nilai pelanggan berpengaruh signifikan terhadap kepuasan pelanggan.

Keberadaan Indomaret di daerah pemukiman penduduk, tentu memberikan dampak bagi toko tradisional dan warung kecil di sekitar wilayah Indomaret beroperasi yaitu berkurangnya pembeli. Hal ini disebabkan oleh karena sebagian para pembeli pindah ke Indomaret dengan bermacam alasan. Berdasarkan hasil wawancara dengan beberapa pelanggan Indomaret di Wilayah Rorotan, bahwa mereka merasa puas berbelanja di Indomaret dikarenakan banyak pilihan dan lengkap untuk keperluan kebutuhan rumah tangga. Oliver (2007) menjelaskan bahwa kepuasan konsumen merupakan bagian dari pemasaran dan memainkan peran penting di pasar. Veloutsou (2005) mendefinisikan kepuasan konsumen secara sederhana sebagai suatu situasi di mana kebutuhan, keinginan dan harapan pelanggan terpenuhi 
melalui produk yang dikonsumsi. Kurniawan (2010) menyatakan bahwa kepuasan konsumen dapat berubah selama periode waktu, hal ini merupakan proses yang dinamis persepsi individu tentang produk atau pelayanan kinerja untuk kepuasan pelanggan. Persaingan yang semakin ketat di mana semakin banyak produsen yang terlibat dalam pemenuhan kebutuhan dan keinginan konsumen, menyebabkan perusahaan harus menempatkan orientasi pada kepuasan konsumen sebagai tujuan utama (Tjiptono, 2004). Dalam proses penyampaian produk kepada pelanggan dan untuk mencapai tujuan perusahaan berupa penjualan produk yang optimal, maka kegiatan pemasaran dijadikan tolak ukur oleh setiap perusahaan.

Kepuasan adalah tingkat perasaan seorang setelah membandingkan kinerja yang dirasakan dengan harapan, jadi tingkat kepuasan adalah fungsi dari perbedaan antara kinerja yang dirasakan dengan harapan. Pelanggan dapat mengalami salah satu dari tiga tingkat kepuasan secara umum. Apabila kinerja di bawah harapan maka pelanggan kecewa, sedangkan apabila kinerja sesuai harapan maka pelanggan puas, selanjutnya apabila kinerja melebihi harapan maka pelanggan puas, senang atau gembira, Kotler (2006). Tingkat Kepuasan konsumen terhadap suatu produk akan memberi loloh balik berupa tingkah laku setelah pembelian. Apabila konsumen puas, mungkin akan membeli lagi produk tersebut di kemudian hari. Konsumen yang puas juga cenderung memberitahukan hal-hal yang baik mengenai produk itu kepada kawan dan kerabatnya. Seorang konsumen yang tidak puas memberi loloh balik yang berbeda, mungkin akan mencari berbagai informasi tentang pembelian, atau bahkan menjelekjelekan produk tersebut kepada kerabatnya.

Hasil penelitian Sarini Kodu (2013), menyatakan bahwa persepsi harga, kualitas produk dan kualitas pelayanan berpengaruh positip dan signifikan terhadap keputusan pembelian. Penelitian lain yang dilakukan oleh Elfri et al. (2014) menyatakan bahwa kualitas pelayanan dan kepuasan konsumen berpengaruh terhadap keputusan pembelian konsumen. Keputusan konsumen merupakan suatu proses pengambilan keputusan yang dilakukan untuk menetapkan kebutuhan akan barang dan jasa yang perlu dibeli serta mengidentifikasi, mengevaluasi dan memilih di antara alternatif merk. Konsumen cenderung membeli produk yang disukai dari segi merek yang paling disukai, dan tugas dari produsen adalah memenuhi keinginan konsumen guna menarik konsumen untuk membeli produk mereka untuk mencapai tujuan perusahaan.

Berdasarkan latar belakang masalah tersebut, maka dilakukan penelitian yang berjudul "Pengaruh Persepsi Harga dan Kualitas Produk terhadap Keputusan Pembelian Konsumen yang Dimediasi Kepuasan Konsumen.”

\section{Rumusan Masalah}

Berdasarkan latar belakang yang ditemukan, maka dapat dirumuskan permasalahan penelitian sebagai berikut : :

1. Apakah persepsi harga berpengaruh terhadap kepuasan konsumen?

2. Apakah persepsi harga berpengaruh terhadap keputusan pembelian konsumen?

3. Apakah kualitas produk berpengaruh terhadap kepuasan konsumen?

4. Apakah kualitas produk berpengaruh terhadap keputusan pembelian konsumen?

5. Apakah kepuasan konsumen berpengaruh terhadap keputusan pembelian konsumen?

\section{Tujuan Penelitian}

Adapun tujuan penelitian ini adalah :

1. Mengetahui pengaruh persepsi harga terhadap kepuasan konsumen.

2. Mengetahui pengaruh persepsi harga terhadap keputusan pembelian konsumen

3. Mengetahui. pengaruh kualiatas produk terhadap kepuasan konsumen.

4. Mengetahui pengaruh kualitas produk terhadap keputusan pembelian konsumen.

5. Mengetahui pengaruh kepuasan konsumen terhadap keputusan pembelian konsumen. 


\section{TINJAUAN PUSTAKA}

\section{Harga}

Kotler dan Armstrong (2007) mengemukakan bahwa harga adalah jumlah uang yang dibebankan atas suatu produk atau jasa. Lebih luas lagi, harga adalah jumlah dari sejumlah nilai yang ditukar konsumen atas manfaat-manfaat memiliki atau menggunakan produk atau jasa tersebut. Di masa lalu harga telah menjadi hal penting yang memengaruhi pilihan pembeli. Harga merupakan salah satu elemen yang fleksibel dari bauran pemasaran, tidak seperti sifatsifat produk dan komitmen jalur distribusi, harga dapat berubah dengan cepat. Pada saat yang sama, penetapan harga dan persaingan harga adalah masalah yang utama yang dihadapi banyak eksekutif pemasaran.

Dari beberapa teori dan penjelasan tentang harga, bahwa indikator harga antara lain terdiri dari (Stanton, 2004):

a. Kualitas Barang/Jasa

Harga sering dijadikan sebagai indikator kualitas bagi konsumen. Misalnya apabila ada barang atau jasa yang harganya mahal, maka konsumen cenderung beranggapan bahwa barang atau jasa tersebut kualitasnya baik. Tingkat harga suatu jasa satu dengan yang lain yang sejenis terkadang memiliki perbedaan, hal ini berdasarkan faktor-faktor penyebabnya. Harga yang diharapkan konsumen untuk sebuah jasa adalah nilai dengan hasil jasa yang ditawarkan.

b. Syarat Pembayaran

Berhubungan dengan bagaimana konsumen akan membayar produk jasa yang akan dibeli, biasanya dalam bentuk tunai dan kredit, tergantung dari kebijaksanaan organisasi.

\section{Persepsi Harga.}

Penilaian yang dirasakan setiap konsumen terhadap suatu barang dan jasa yang mereka terima tidak sama, banyak faktor yang dapat memengaruhinya. Persepsi konsumen terhadap suatu harga dapat memengaruhi keputusannya dalam membeli suatu produk. Oleh karena itu setiap produsen akan berusaha memberikan persepsi yang baik terhadap produk atau jasa yang mereka jual. Menurut Hawkins et al. (1986), persepsi adalah sebuah proses yang diawali dengan pemaparan konsumen dan perhatian terhadap rangsangan pemasaran dan berakhir dengan penafsiran oleh konsumen". Terdapat 2 (dua) faktor yang memengaruhi persepsi terhadap kewajaran suatu harga. Pertama,persepsi tentang perbedaan harga. Pembeli cenderung melakukan evaluasi terhadap perbedaan harga antara harga yang ditawarkan terhadap harga dasar yang diketahui. Faktor lain yang memengaruhi persepsi terhadap kewajaran suatu harga adalah referensi harga yaitu dimiliki oleh pelanggan yang didapat dari pengalaman sendiri (harga internal) dan informasi luar iklan dan pengalaman orang lain (referensi harga eksternal).

Pada saat pemprosesan informasi harga secara kognitif, konsumen dapat membuat perbandingan antara harga yang ditetapkan dengan harga atau rentang harga yang telah terbentuk dalam benak mereka untuk produk tersebut. Harga dalam benak konsumen yang digunakan untuk melakukan perbandingan ini disebut harga referensi internal. Referensi harga internal pada dasarnya bertindak sebagai penuntun dalam mengevaluasi apakah harga yang ditetapkan dapat diterima konsumen atau tidak. Kotler menjelaskan faktor-faktor yang memengaruhi persepsi, yaitu :

1) Perhatian Selektif

$\begin{array}{lcc}\text { Orang-orang } & \text { mungkin } & \text { lebih } \\ \text { memperhatikan } & \text { stimulasi } & \text { yang }\end{array}$ berhubungan dengan kebutuhan saat ini, stimulasi yang kalau diantisipasi serta stimulasi yang besar dalam kaitannya dengan ukuran normal.

2) Distorsi Selektif

Menjelaskan kecenderungan orang untuk mengolah informasi menjadi suatu pengertian pribadi.

3) Ingatan Selektif

Orang-orang akan melupakan kebanyakan dari hal yang mereka pelajari dan cenderung mempertahankan informasi yang mendukung pendirian dan kepercayaan mereka. 
Persepsi harga dibentuk oleh 2 (dua) dimensi utama yaitu :

1. Persepsi Kualitas

Konsumen cenderung lebih menyukai produk yang harganya mahal ketika kualitas yang didapat melebihi harga produknya. Persepsi konsumen terhadap kualitas suatu produk meliputi:

a) Persepsi Nama Merek

Nama sebuah merek dapat mengindikasikan kualitas suatu produk. Merek yang sudah lama dan memiliki citra yang kuat terhadap sebuah produk biasanya akan lebih cepat diingat oleh konsumen.

b) Persepsi Nama Toko Dealer Reputasi nama toko/dealer akan menciptakan persepsi konsumen terhadap produk yang ditawarkan, baik dari segi kualitas maupun harganya. Kenyamanan toko, layout dan kualitas pelayanan yang diterima konsumen akan menimbulkan persepsi tersendiri terhadap reputasi toko/dealer tersebut.

c) Persepsi Garansi

Produk yang menawarkan garansi bagi para konsumen sering identik dengan produk yang memiliki kualitas tinggi. Konsumen akan merasa lebih tenang dalam menggunakan produk tersebut, karena pihak perusahaan menjamin kualitasnya.

d) Persepsi Negara yang Menghasilkan Produk

Kualitas sebuah produk sering dikaitkan dengan negara pembuatnya. Oleh karena itu konsumen dapat langsung memiliki persepsi terhadap suatu produk hanya dengan mengetahui dari negara mana produk tersebut berasal.

2. Persepsi Biaya yang Dikorbankan

Secara umum konsumen menganggap bahwa harga merupakan biaya yang dikeluarkan atau dikorbankan untuk mendapatkan produk. Akan tetapi konsumen mempunyai persepsi yang berbeda-beda terhadap biaya yang dikeluarkan meskipun untuk produk yang sama. Hal ini tergantung situasi dan kondisi yang dialami oleh konsumen, dalam hal ini terdapat 3 (tiga) kondisi yang memengaruhi persepsi konsumen terhadap biaya yang dikeluarkan, yaitu :

a) Persepsi terhadap Pajak Konsumen memiliki penilaian yang berbeda terhadap biaya pajak yang harus dibayarkan. Untuk 2 (dua) produk yang berbeda konsumen memiliki penilaian yang berbeda meskipun biaya atau harga yang dikeluarkan untuk mendapatkan produk tersebut nilainya sama.

b) Persepsi terhadap Kewajaran Harga

Terdapat 2 (dua) tipe transaksi yang dapat memengaruhi penilaian konsumen terhadap wajar atau tidaknya harga suatu produk, yaitu :

1) Konsumen akan menganggap harga yang diterapkan tidak wajar apabila penjual menaikkan harga produk untuk memperoleh keuntungan dari permintaan yang terus meningkat, penjual menaikkan harga produk karena alasan kelangkaan barang, penjual menaikkan harga produk untuk menutupi biaya produksi yang meningkat.

2) Konsumen akan menganggap harga yang diterapkan tidak wajar, apabila pada saat transaksi terjadi, terdapat pembeli lain yang memperoleh harga lebih rendah dan kualitas produk yang lebih baik, sedangkan dia sendiri tidak.

c) Efek Ekuitas Merek

Menurut Kotler dan Armstrong (2007), ekuitas merek adalah efek diferensial positif yang ditimbulkan oleh pengetahuan 
nama merek terhadap tanggapan pelanggan atas jasa produk tersebut. Ekuitas merek yang sudah kuat sering dipersepsikan dengan harga yang premium. Konsumen akan bersedia membayar dengan harga yang lebih tinggi untuk memperoleh produk yang berkualitas dan memiliki image merek yang lebih superior.

\section{Kualitas Produk}

Kualitas produk merupakan suatu hal yang harus dipenuhi oleh perusahaan karena kualitas produk yang baik merupakan kunci dari perkembangan produktivitas perusahaan. Secara luas produk dapat diartikan sebagai segala sesuatu yang ditawarkan oleh pemasar kepada konsumen untuk memenuhi keinginan dan kebutuhan, termasuk pula barang fisik, jasa, pengalaman, acara, tempat, orang, properti, organisasi, informasi, maupun ide (Kotler \& Keller, 2009).

Gasper (1997) menyatakan bahwa kelengkapan produk menyangkut lingkup layanan dan ketersediaan sarana pendukungnya. Produk sendiri meliputi barang-barang yang dijual atau ditawarkan oleh peritel di mana produk tersebut berpengaruh pada citra toko yang baik ketika dapat menyediakan barang atau jasa yang dibutuhkan oleh konsumen.

Terdapat beberapa faktor yang dipertimbangkan dalam memilih produk yang akan dijual menurut, diantaranya yaitu:

1. Variety (kelengkapan produk)

Seberapa jauh perusahaan dapat menyediakan produk sesuai dengan kebutuhan dan keinginan konsumen.

2. Width of breath (keluasan)

Ketersediaan produk-produk pelengkap dari produk utama yang ditawarkan.

3. Depth (kedalaman)

Macam dan jenis dari suatu produk yang ditawarkan, misalnya warna, ukuran jumlah, dan karakteristik.

4. Consistency (keruntutan)

Peritel harus dapat menyeimbangkan antara citra yang ada dalam benak konsumen terhadap produk yang ditawarkan di gerai.

\section{Balance (keseimbangan)}

Retailer harus dapat menyeimbangkan antara produk utama dengan produk pelengkap yang ditawarkan di gerai.

6. Flexibility (kelenturan)

Produk yang ditawarkan harus selalu diperbarui dan disesuaikan dengan mode dan trend saat ini.

Menurut Tjiptono (2008), kualitas mencerminkan semua dimensi penawaran produk yang menghasilkan manfaat (benefits) bagi pelanggan. Kualitas suatu produk baik berupa barang atau jasa ditentukan melalui dimensi-dimensinya. Dimensi kualitas produk adalah:

1. Performance (kinerja), berhubungan dengan karakteristik operasi dasar dari sebuah produk.

2. Durability (kedayatahanan), yang berarti berapa lama atau umur produk yang bersangkutan bertahan sebelum produk tersebut harus diganti. Semakin besar frekuensi pemakaian konsumen terhadap produk maka semakin besar pula daya produk.

3. Conformance to specifications (kesesuaian dengan spesifikasi), yaitu sejauh mana karakteristik operasi pasar dari sebuah produk memenuhi spesifikasi tertentu dari konsumen atau tidak ditemukannya cacat pada produk.

4. Features (fitur), adalah karakteristik produk yang dirancang untuk menyempurnakan fungsi produk atau menambah ketertarikan konsumen terhadap produk.

5. Reliability (keandalan), adalah probabilitas bahwa produk akan bekerja dengan memuaskan atau tidak dalam periode waktu tertentu. Semakin kecil kemungkinan terjadinya kerusakan maka produk tersebut dapat diandalkan.

6. Aesthetics (estetika), berhubungan dengan bagaimana penampilan produk.

7. Perceived quality (kualitas terpersepsi), adalah hasil dari penggunaan pengukuran yang dilakukan secara tidak langsung karena terdapat kemungkinan bahwa konsumen tidak mengerti atau kekurangan informasi atas produk yang bersangkutan. 
8. Serviceability, meliputi kecepatan dan kemudahan untuk direparasi, serta kompetensi dan keramahan staf layanan.

\section{Kepuasan Pelanggan}

Boone dan Kurtz (2007)

menyatakan bahwa kepuasan pelanggan adalah sebagai hasil dari barang atau jasa yang memenuhi atau melebihi kebutuhan dan harapan pembeli. Konsep dari barang atau jasa yang memberikan kepuasan pembeli karena bisa memenuhi atau melebihi harapan mereka adalah hal yang penting bagi operasi perusahaan. Sebuah perusahaan yang gagal untuk memenuhi kepuasan pelanggan dibandingkan dengan kompetitornya tidak akan bertahan di bisnis dalam waktu yang lama. Pelanggan yang merasa puas akan kembali membeli, dan mereka akan memberitahu yang lain tentang pengalaman baik mereka dengan produk tersebut. Kuncinya adalah menyesuaikan harapan pelanggan dengan kinerja perusahaan. Perusahaan yang pintar bermaksud untuk memuaskan pelanggan dengan hanya menjanjikan apa yang dapat mereka berikan, kemudian memberikan lebih banyak dari apa yang mereka janjikan.

Oliver dalam (Barnes, 2003:64) menyatakan kepuasan adalah tanggapan pelanggan atas terpenuhinya kebutuhan, yang berarti bahwa penilaian pelanggan atas barang atau jasa memberikan tingkat kenyamanan yang terkait dengan pemenuhan suatu kebutuhan termasuk pemenuhan kebutuhan yang tidak sesuai harapan atau pemenuhan yang melebihi harapan pelanggan. Menurut Amir (2005: 13) kepuasan pelanggan adalah sejauh mana manfaat sebuah produk dirasakan (perceived) sesuai dengan apa yang diharapkan pelanggan, merasa tidak puas apabila hasilnya tidak sesuai dengan harapan. Menurut Richard F Gerson (2002 : 3) kepuasan pelanggan adalah persepsi pelanggan bahwa harapannya telah terpenuhi dan terlampaui. Terdapat dua kepuasan pelanggan, yaitu :

a) Kepuasan fungsional, merupakan kepuasan yang diperoleh dari fungsi suatu produk/jasa yang dimanfaatkan. b) Kepuasan psikologikal, merupakan kepuasan yang diperoleh dari atribut yang tidak berwujud dari suatu produk/jasa.

Tingkat kepuasan konsumen dapat ditentukan berdasar pada lima (5) faktor utama yang harus diperhatikan oleh sebuah perusahaan Amir (2005: 13) menyatakan, kepuasan pelanggan adalah sejauh mana manfaat sebuah produk terpersepsi sesuai dengan apa yang diharapkan pelanggan, merasa tidak puas apabila hasilnya tidak sesuai dengan harapan. Menurut Richard F Gerson (2002 : 3) yaitu:

1. Kualitas produk

Konsumen akan merasa puas apabila hasil evaluasi mereka menunjukkan bahwa produk yang mereka gunakan berkualitas.

2. Kualitas layanan

Konsumen akan merasa puas apabila mereka mendapatkan layanan yang sesuai yang diharapkan terutama untuk industri jasa.

3. Emosional

Konsumen akan merasa bangga dan mendapatkan keyakinan bahwa orang lain akan kagum terhadap konsumen tersebut apabila menggunakan merek tertentu yang cenderung mempunyai tingkat kepuasan.

4. Harga

Produk yang mempunyai kualitas yang sama tetapi menetapkan harga yang relatif murah akan memberikan nilai lebih tinggi kepada konsumennya.

5. Biaya

Konsumen tidak perlu mengeluarkan biaya tambahan atau tidak perlu membuang waktu untuk mendapatkan suatu produk atau jasa, cenderung puas terhadap produk atau jasa tersebut.

\section{Keputusan Pembelian Konsumen}

Keputusan pembelian menurut Kotler (2007) adalah tahap dalam proses pengambilan keputusan pembeli di mana konsumen benar-bernar akan membeli. Definisi keputusan pembelian menurut Nugroho (2003) adalah proses pengintegrasian yang mengombinasikan sikap pengetahuan untuk mengevaluasi dua 
atau lebih perilaku alternatif dan memilih salah satu diantaranya

Dimensi untuk mengukur keputusan pembelian konsumen menurut Sutisna (2003) adalah :

\section{Benefit association}

Konsumen menemukan manfaat yang digunakan dari produk yang dibeli dan menghubungkan kriteria manfaat itu dengan karakteristik merek. Kriteria manfaat yang bisa diambil adalah kemudahan mengingat nama produk ketika dihadapkan dalam keputusan membeli produk.
2. Frekuensi pembelian

Ketika konsumen membeli produk tertentu dan ia merasa puas dengan kinerja produk tersebut, maka ia akan sering membeli kembali produk tersebut kapan pun dia membutuhkannya.

\section{Kerangka Pemikiran dan Hipotesis}

Penelitian ini terdiri dari peubah bebas yaitu persepsi harga $(\mathrm{PH})$ dan kualitas produk (KP), dan memiliki peubah pengantara kepuasan konsumen (KK), sedangkan peubah gayut adalah keputusan pembelian konsumen (KPK). Berdasarkan kajian teori dan penelitian-penelitian terdahulu, maka dapat disusun sebuah rerangka pemikiran teoritis seperti yang tersaji dalam gambar berikut.

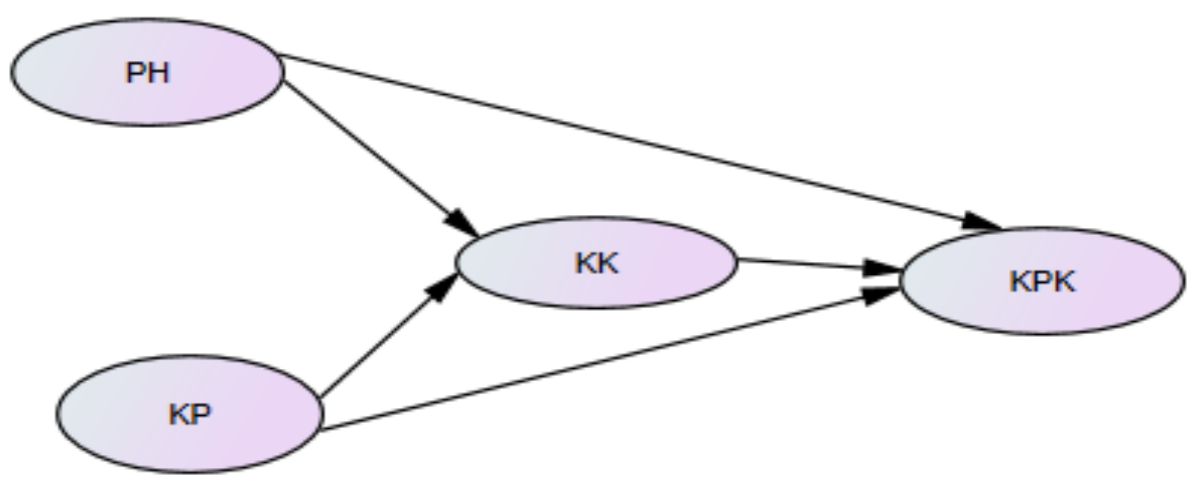

Gambar 1. Model Penelitian

Sumber. Hasil Pengolahan teori, 2016

Berdasarkan rerangka pemikiran teoritis tersebut dapat dibangun hipotesis sebagai berkut :

\section{Persepsi Harga berpengaruh terhadap Kepuasan Pelanggan.}

Menurut Zeithaml (2002) pengertian harga dari konsep kognitif pelanggan adalah sesuatu yang harus dikorbankan untuk mendapatkan beberapa jenis produk dan jasa, di mana semakin rendah harga yang dirasakan maka semakin rendah pula pengorbanan yang dirasakan dan pelanggan lebih puas akan harga yang dirasakan dari keseluruhan transaksi yang diciptakan. Pelanggan menggunakan harga sebagai petunjuk pembelian, ini menyiratkan bahwa harga yang lebih rendah atau harga moneter tidak menjamin kepuasan yang lebih tinggi.

Hermann et al. (2007) dalam penelitiannya menunjukkan bahwa persepsi harga secara langsung memengaruhi penilaian kepuasan. Secara empiris penelitian ini telah mengaitkan kedua konsep penting dan menunjukkan pengaruh persepsi harga.

Berdasarkan uraian tersebut, maka hipotesis yang akan diuji dalam penelitian adalah:

H1 : Persepsi harga berpengaruh positif terhadap kepuasan konsumen 
2. Pengaruh persepsi harga terhadap keputusan pembelian konsumen

Tan (2011) dalam penelitiannya menunjukan bahwa harga, promosi penjualan pelayanan mempunyai pengaruh serempak dan signifikan terhadap keputusan konsumen untuk berbelanja. Owusu Alfred (2013) dalam penelitiannya menunjukan bahwa harga dan kualitas memiliki pengaruh pada keputusan pembelian konsumen dan konsumen mempertimbangkan harga dan kualitas dalam situasi pembelian mereka. Berdasarkan uraian tersebut maka hipotesis yang dapat diuji adalah: $\mathrm{H} 2$ : Persepsi harga berpengaruh positif terhadap keputusan pembelian konsumen

3. Pengaruh kualitas produk terhadap kepuasan konsumen

Lonardo et al. (2014) dalam penelitiannya menyatakan bahwa kualitas produk yang menjadi pengaruh terbesar bagi kepuasan konsumen, setelah harga. Demikian juga Suci Widyawati et al. (2012) dalam penelitiannya menyatakan bahwa kualitas produk, harga, dan nilai pelanggan berpengaruh signifikan terhadap kepuasan pelanggan. Berdasarkan uraian tersebut maka hipotesis yang dapat diuji adalah:

H3 : Kualitas produk berpengaruh positif terhadap kepuasan konsumen

4. Pengaruh kualitas produk terhadap keputusan pembelian konsumen

Penelitian Rajput et al. (2012) tentang pengaruh harga dan kualitas produk terhadap perilaku pembelian menunjukan bahwa terdapat hubungan yang positif dan signifikan antara harga produk dengan perilaku pembelian dan terdapat hubungan yang negatif dan signifikan antara kualitas produk dengan perilaku pembelian.

Berdasarkan uraian tersebut maka hipotesis yang dapat diuji adalah:

H4 : Kualitas produk berpengaruh positif terhadap keputusan pembelian konsumen.

\section{Pengaruh kepuasan konsumen terhadap keputusan pembelian konsumen}

Bei dan Chiao (2001) menyatakan seorang pelanggan akan menampilkan perilaku pembelian berulang ketika mereka merasakan bahwa harga layanan dan produk yang ditawarkan masuk akal. Jika pelanggan tidak merasa pengorbanan mereka berharga, mungkin mereka tidak melakukan pembelian lagi, bahkan ketika mereka tidak merasa puas dengan produk atau jasa. Hasil dari penelitian ini, yaitu harga yang dirasakan positif berkaitan dengan keputusan pembelian kembali melalui kepuasan konsumen.

Penelitian lain yang dilakukan oleh Elfri et al. (2014) menyatakan bahwa kualitas pelayanan dan kepuasan konsumen berpengaruh terhadap keputusan pembelian konsumen. Berdasarkan uraian tersebut maka hipotesis yang dapat dirumuskan adalah:

H5 : Kepuasan konsumen berpengaruh positif terhadap keputusan pembelian konsumen

\section{METODE PENELITIAN}

\section{Desain Penelitian}

Penelitian ini menggunakan studi penjelasan (explanatory research), yakni menjelaskan suatu hubungan antara peubah melalui pengujian hipotesis (Ghozali, 2005:2). Model yang digunakan dalam penelitian ini adalah model kausalitas yaitu suatu penelitian yang bertujuan untuk menentukan pengaruh di antara peubah bebas dan peubah tidak bebas. Hubungan antara peubah bebas (persepsi harga dan kualitas produk ) dengan peubah gayut (keputusan pembelian konsumen) yang dimediasi kepuasan konsumen. 


\section{Operasionalisasi Peubah dan Skala Pengukuran}

Dalam penelitian ini peubah peubah gayut. Identifikasi peubah yang digunakan meliputi :

diklasifikasikan menjadi peubah bebas dan

Tabel 2. Operasionalisasi dan Pengukuran Peubah Penelitian

Sumber : Hasil pengolahan (2015)

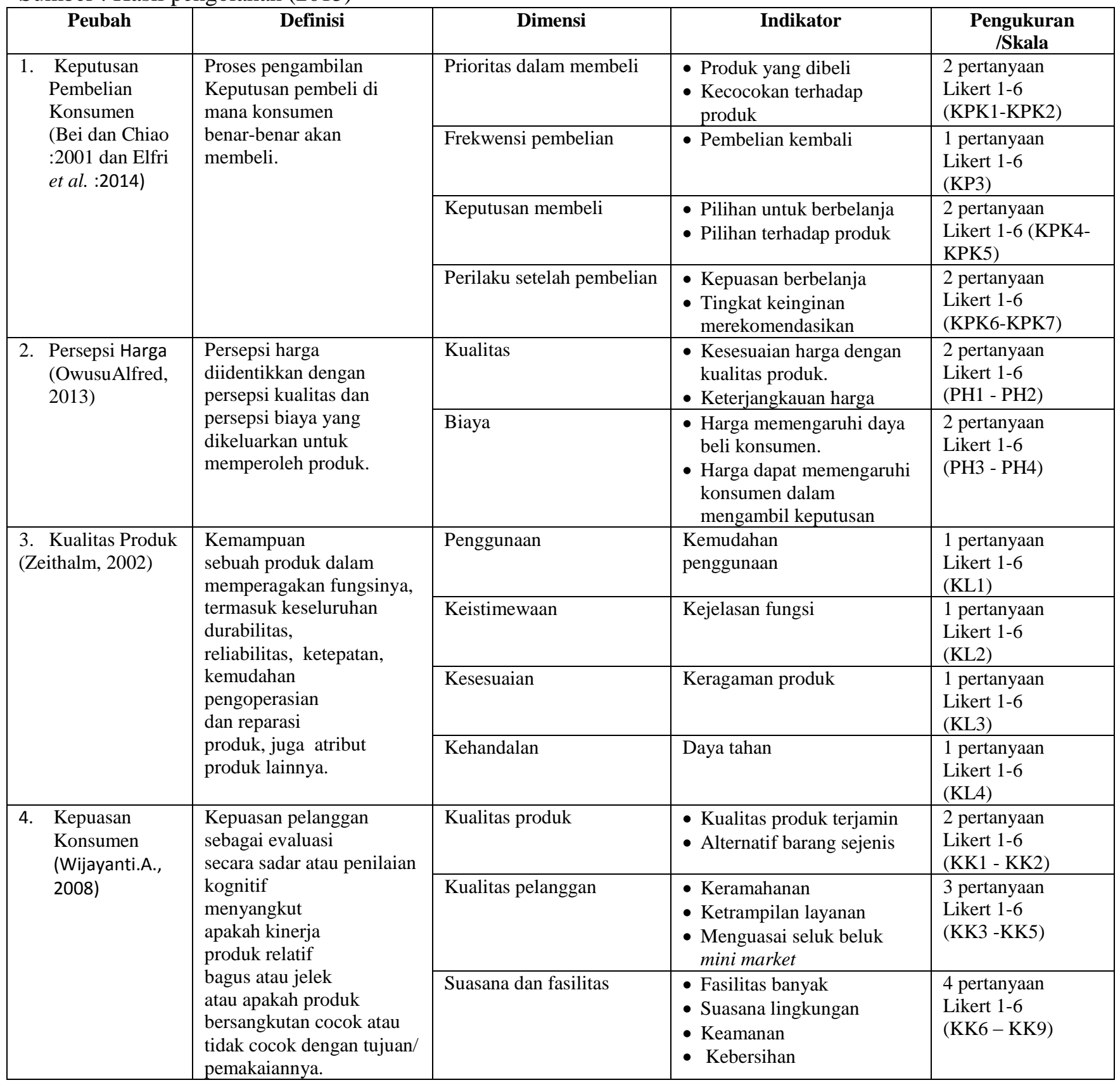

\section{Populasi dan Sample}

Menurut William dalam (Pardede, R., Reinhard M., 2014 : 8), populasi adalah kelompok lengkap orang, perusahaan, rumah sakit, tokoh, mahasiswa atau sejenisnya yang memiliki beberapa set karakteristik. Dalam penelitian ini populasinya adalah konsumen yang telah melakukan pembelian di mini market Indomaret Rorotan Jakarta Utara. Karena jumlah populasi yang relatif 
banyak, maka digunakan metode pengambilan sampel.

Sampel adalah himpunan bagian (subset) dari populasi. Penarikan dengan sampel dilakukan mengingat keterbatasan waktu, tenaga, dan dana, menghadapi populasi yang begitu banyak. Data yang diperoleh dari sampel tersebut kemudian dipelajari dan ditarik kesimpulan yang berlaku untuk populasi. Karena sampel ini merupakan sebagian jumlah yang mewakili populasi, maka sampel harus representatif.

Teknik sampel yang digunakan dalam penelitian ini adalah teknik aksidental. Pengambilan sampel dengan teknik aksidental (accidental sampling) adalah teknik penentuan sampel berdasarkan kebetulan atau siapa saja yang bertemu dengan peneliti dapat dijadikan sebagai sampel, dan bila orang yang ditemui tersebut dipandang cocok sebagai sumber data (Sugiyono, 2001:96).

Dalam penelitian ini, peneliti akan memberikan kuesioner pada konsumen yang sudah melakukan pembelian pada mini market Indomaret Rorotan Jakarta Utara. Karena jumlah populasi dalam penelitian ini tidak diketahui, maka jumlah sampel yang diperlukan adalah paling sedikit 4 atau 6 kali jumlah butir yang diteliti, Maholtra (1996:620). Karena jumlah butir yang diteliti adalah sebanyak 25 butir, maka sampel yang ditetapkan sebanyak 150 responden.

\section{Teknik dan Analisis Data}

Penelitian ini menggunakan teknik analisis data, yaitu Analisis Normality, Analisis Structural Modeling (SEM) dan analisis Hypotesis yang terdiri atas pengaruh langsung dan tidak langsung. Untuk mendapatkan pengaruh langsung dan tidak langsung digunakan analisis jalur dengan menggunakan peubah penggangu. Peubah pengganggu tersebut merupakan peubah pengantara yang berfungsi memediasi kaitan antara peubah bebas dengan peubah gayut.

Metode SEM digunakan dalam penelitian ini dengan alasan latar belakang penelitian yang bersifat kausalitas (hubungan sebab akibat/pengaruh). Pemodelan SEM merupakan analisis yang cukup kompleks karena merupakan gabungan dari model regresi dan analisis jalur untuk melihat pengaruh kausal, pengaruh langsung dan tidak langsung (Bollen, 1989 dalam Sumarwan, et al. 2013). Adapun model persamaan struktural penelitian ditunjukkan pada Gambar 2.

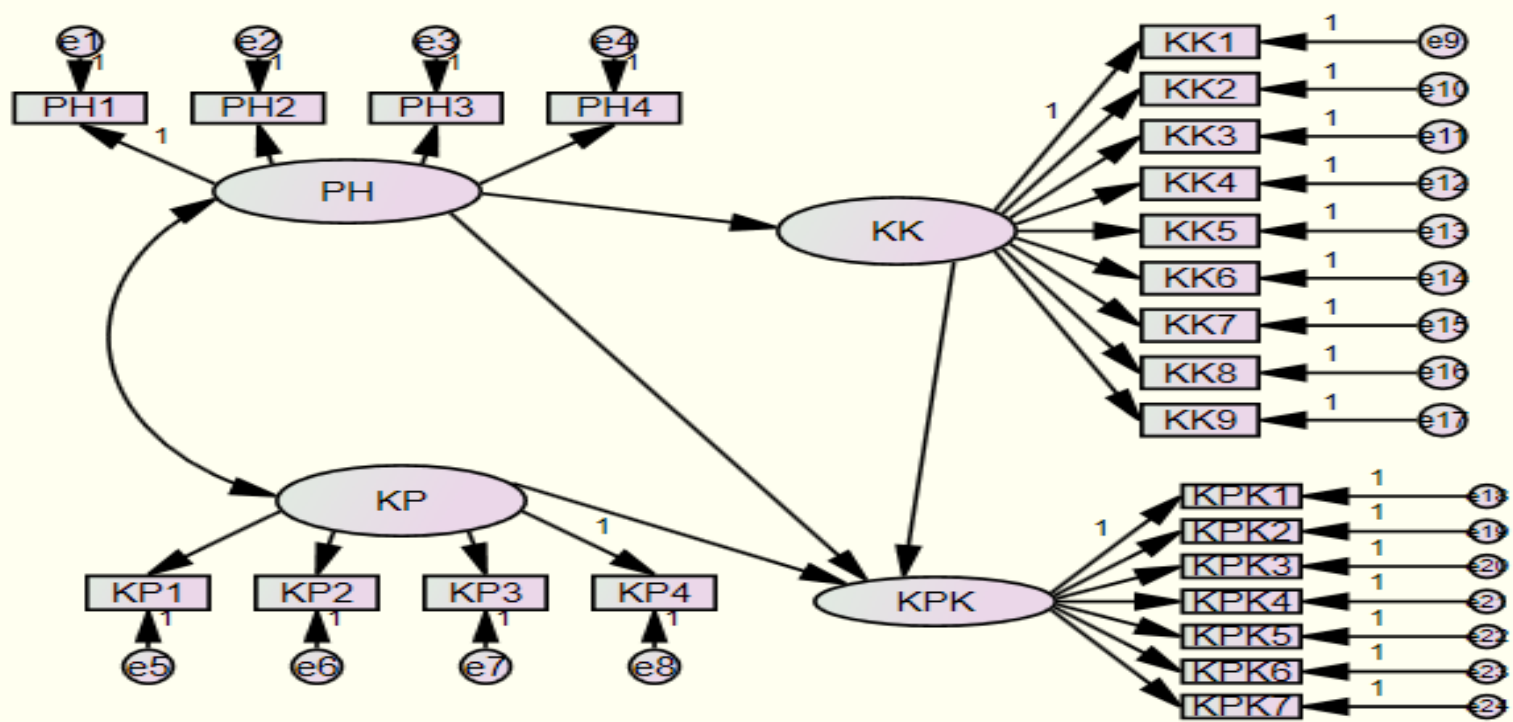

Gambar 2. Model Persamaan Struktural Penelitian

Sumber : (Hasil olahan, 2016) 


\section{HASIL DAN PEMBAHASAN}

\section{Analisis Deskriptif.}

Profil Responden

Responden penelitian ini adalah konsumen Indomaret yang berdomisili di wilayah Rorotan. Dalam penelitian ini, koesioner yang disebarkan sebanyak 150 eksemplar.

Responden yang telah dipilih dapat dikatakan cukup mewakili karakteristik populasi penduduk di wilayah Kalurahan Rorotan, Jakarta Utara karena terdiri dari beberapa elemen berdasarkan: jender (pria dan wanita), usia (di bawah 19 - 25 tahun ke atas), dan frekuensi berbelanja barang serta alasan berbelanja di Indomaret .

Berdasarkan data responden yang ada, diperoleh beberapa informasi dan gambaran demografis berdasarkan jenis kelamin, usia, dan frekuensi berbelanja barang serta alasan berbelanja di Indomaret. Berikut ini merupakan deskripsi demografis responden penelitian:

\section{a. Responde Berdasarkan jender}

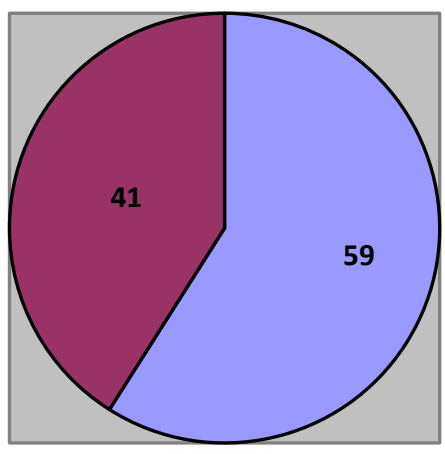

口erempuan

口Laki-laki

Gambar 3. Responden berdasarkan jenis kelamin

Sumber : (Hasil olahan, 2016)

Berdasarkan data Gambar 3. dapat diketahui bahwa perbandingan jumlah responden berdasarkan jender agak berimbang, di mana jumlah responden wanita lebih banyak, yaitu 88 orang atau $59 \%$, sedangkan responden laki-laki berjumlah 62 orang atau $41 \%$ dari total 150 responden

\section{b. Responden Berdasarkan Umur}

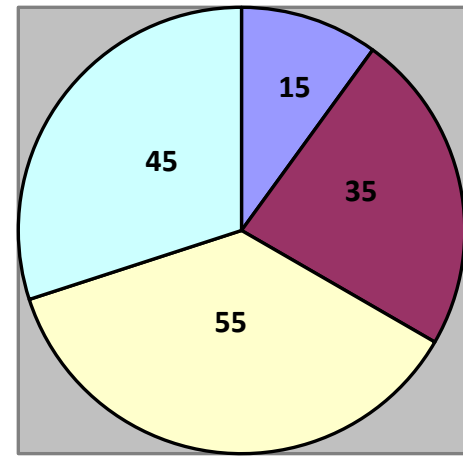

Gambar 4. Responden berdasarkan umur

Sumber : (Hasil olahan, 2016) 
Data dari Gambar 4 menunjukkan bahwa rentang usia responden penelitian ini cukup besar yaitu dari usia di bawah 19 tahun hingga usia di atas 25 tahun. Usia responden yang bervariasi ini kemudian dikelompokkan menjadi rentang usia di bawah 19 tahun, dengan jumlah responden sebanyak 15 orang atau $10 \%$; usia $19-21$ tahun, dengan jumlah responden sebanyak 35 orang atau 23\%; usia 22 - 25 tahun dengan jumlah responden 55 orang atau $37 \%$; dan usia 25 tahun ke atas dengan jumlah responden sebanyak 45 orang atau $30 \%$.

\section{c. Responden Berdasarkan Frekuensi Berbelanja}

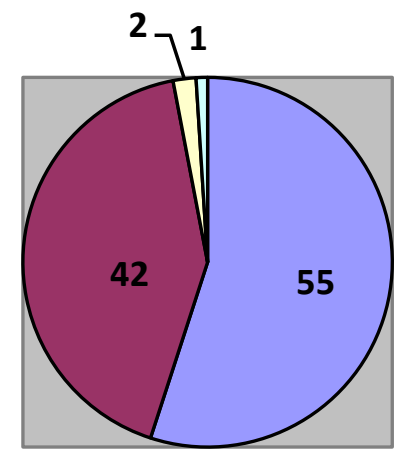

\section{$\square$ Sangat sering \\ $\square$ Sering \\ $\square$ Jarang \\ $\square$ Sangat jarang}

\section{Gambar 5. Responden berdasarkan frekuensi belanja}

Sumber : (Hasil olahan, 2016)

Gambar 5. menunjukkan bahwa sebagian besar responden sangat sering berbelanja di Indomaret. Adapun responden yang sangat sering berbelanja sebanyak 83

orang atau 55\%, sering sebanyak 64 orang atau $42 \%$, jarang sebanyak 3 orang atau $2 \%$ sedangkan yang sangat jarang 1 orang atau $1 \%$.

\section{d. Responden Berdasarkan Alasan Berbelanja}

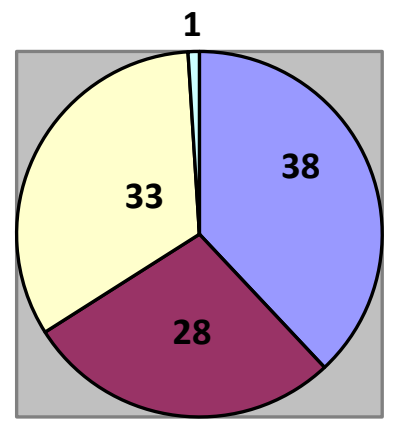

$\square$ Dekat rumah
$\square$ Barang lengkap
$\square$ Harga murah
$\square$ Lain-lain

Gambar 6. Alasan responden berbelanja

Sumber : (Hasil olahan, 2016) 
Berdasarkan Gambar 6. dapat diketahui bahwa sebagian besar responden berbelanja disebabkan dekat rumah, terlihat sebanyak 57 orang atau $38 \%$, barang lengkap sebanyak 43 orang atau $28 \%$, harga murah sebanyak 50 orang atau $33 \%$, sedangkan lain-lain sebanyak 2 atau $1 \%$.

\section{Hasil Pengujian Instrumen Penelitian}

Uji Kesahihan dan Keandalan

Uji kesahihan dilakukan untuk menunjukkan bahwa indikator yang digunakan untuk mengukur peubah sudah cocok, tepat dan memuaskan. Kriteria untuk uji kesahihan adalah nilai Corrected ItemTotal Correlation > 0,3494 untuk 30 responden, dengan $r=0,05$. Uji keandalan yang dilakukan ini akan menunjukkan konsistensi tiap-tiap indikator. Kriteria uji keandalan ialah koefisien Cronbach's Coefficient $\alpha>0,6$. Hasil uji keandalan dan kesahihan ditunjukkan dalam Tabel 3.

Tabel 3. Hasil Uji Reliabilitas dan validitas

\begin{tabular}{|c|c|c|c|}
\hline Peubah & Indikator & $\begin{array}{l}\text { Corected Item-Total } \\
\text { Correlation }\end{array}$ & $\begin{array}{l}\text { Cronbach's } \\
\text { Coefficient }\end{array}$ \\
\hline \multirow{4}{*}{$\begin{array}{l}\text { Persepsi } \\
\text { Harga }\end{array}$} & PH1 & 0.537 & \multirow{4}{*}{0.750} \\
\hline & $\mathrm{PH} 2$ & 0.773 & \\
\hline & PH3 & 0.827 & \\
\hline & PH4 & 0.762 & \\
\hline \multirow{4}{*}{$\begin{array}{l}\text { Kualitas } \\
\text { Produk }\end{array}$} & KP1 & 0.795 & \multirow{4}{*}{0.867} \\
\hline & KP2 & 0.848 & \\
\hline & KP3 & 0.790 & \\
\hline & KP4 & 0.901 & \\
\hline \multirow{9}{*}{$\begin{array}{l}\text { Kepuasan } \\
\text { Konsumen }\end{array}$} & KK1 & 0.710 & \multirow{9}{*}{0.888} \\
\hline & KK2 & 0.638 & \\
\hline & KK3 & 0.654 & \\
\hline & KK4 & 0.804 & \\
\hline & KK5 & 0.611 & \\
\hline & KK6 & 0.620 & \\
\hline & KK7 & 0.617 & \\
\hline & KK8 & 0.461 & \\
\hline & KK9 & 0.331 & \\
\hline \multirow{7}{*}{$\begin{array}{l}\text { Keputusan } \\
\text { Pembelian } \\
\text { Konsumen }\end{array}$} & KPK1 & 0.702 & \multirow{7}{*}{0.833} \\
\hline & KPK2 & 0.616 & \\
\hline & KPK3 & 0.646 & \\
\hline & KPK4 & 0.746 & \\
\hline & KPK5 & 0.546 & \\
\hline & KPK6 & 0.502 & \\
\hline & KPK7 & 0.493 & \\
\hline
\end{tabular}

Tabel 3 menunjukkan nilai keandalan dan kesahihan dari tiap-tiap indikator, sebagai berikut : Uji reliabilitas peubah persepsi harga yang memiliki 2 dimensi dengan 4 indikator, menghasilkan nilai Cronbach's Coefficient $\alpha>0,6$ yaitu 0.750, artinya indikator-indikator pengukuran untuk persepsi harga reliabel.
Selanjutnya uji kesahihan indikator menunjukkan bahwa nilai Corrected ItemTotal Correlation semua indikatornnya > 0,3494 , artinya semua indikator pengukuran persepsi harga sahih.

Uji keandalan peubah kualitas produk yang memiliki 4 dimensi dengan 4 indikator, menghasilkan nilai Cronbach's 
Coefficient $\alpha>0,6$ yaitu 0.867, artinya indikator-indikator pengukuran untuk kualitas produk handal. Selanjutnya uji kesahihan indikator menunjukkan bahwa nilai Corrected Item-Total Correlation semua indikatornya $>0,3494$, artinya semua indikator pengukuran kualitas produk sahih.

Uji keandalan peubah kepuasan konsumen memiliki 3 dimensi dengan 9 indikator, menghasilkan nilai Cronbach's Coefficient $\alpha>0,6$ yaitu 0,888 , artinya indikator-indikator pengukuran untuk kepuasan konsumen handal. Selanjutnya uji validitas menunjukkan bahwa nilai Corrected Item-Total Correlation salah satu indikator, yakni KK9<0,3494, yaitu senilai 0,331. Dengan demikian indikator KK 9 (kebersihan) tidak sahih, sehingga dikeluarkan dari model.

Uji keandalan peubah keputusan pembelian konsumen memiliki 4 dimensi dan 4 indikator, menghasilkan nilai Cronbach's Coefficient $\alpha>0,6$ yakni 0,833, artinya indikator-indikator pengukuran keputusan pembelian konsumen handal. Selanjutnya uji kesahihan menunjukkan bahwa nilai Corrected Item-Total Correlation semua indikator keputusan pembelian konsumen > 0,3494, dengan demikian sahih. Setelah dilakukan ujji keandalan terhadap ke 4 peubah diperoleh 23 indikator teruji yang memenuhi persyaratan kesahihan dan keandalan.

\section{Hasil Analisis Statistik Inferensial}

Analisis Confirmatory Faktor (CFA) dan Regression Weight

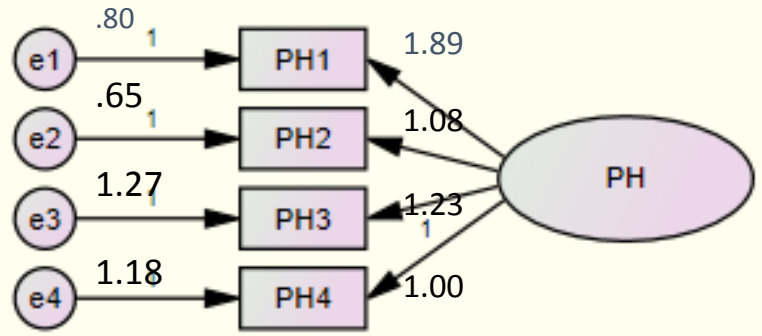

Gambar 7. Analisis Faktor Konfirmatori Peubah Persepsi Harga

Sumber : Olah data AMOS 22, 2016

Tabel 4. Regression Weights (Peubah Persepsi harga)

\begin{tabular}{|c|c|c|c|c|c|}
\hline & Estimate & S.E & C.R. & $\mathrm{P}$ & Label \\
\hline PH4 $\longleftarrow$ PH & 1.00 & & & & Par_1 \\
\hline PH3 & 1.229 & .604 & 2.034 & 0.042 & Par_2 \\
\hline $\mathrm{PH} 2 \longleftarrow$ PH & 1.080 & .506 & 2.134 & .033 & Par_3 \\
\hline PH1 $\longleftarrow$ PH & 1.895 & 1.014 & 1.870 & .062 & $\mathrm{Par}_{-4}$ \\
\hline
\end{tabular}

Berdasarkan hasil pengujian seperti terlihat dalam Gambar 7. dan Tabel 4., koefisien masing-masing indikator peubah persepsi harga memiliki loading factor $>0.40$ pada diagram path dan untuk mengetahui kuatnya dimensi yang membentuk faktor latent dapat dilihat dari bobot faktor. yang dapat dianalisis dengan menggunakan uji-t identik dengan nilai Critical ratio (CR), di mana indikator 2.0, kecuali indikator PH1 memiliki nilai $\mathrm{CR}$ 1.870 


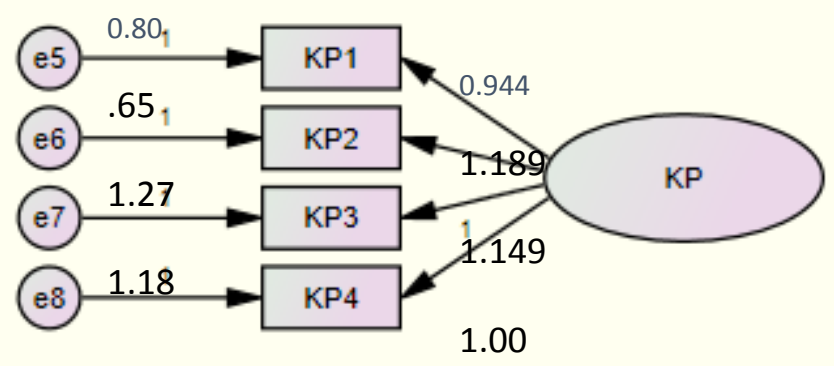

Gambar 8. Analisis Faktor Konfirmatori Peubah Kualitas

Sumber : Olah data AMOS 22, 2016

Tabel 5. Regression Weights (Peubah Persepsi Harga)

\begin{tabular}{|c|c|c|c|c|c|}
\hline & Estimate & S.E & C.R. & $\mathrm{P}$ & Label \\
\hline KP4 & 1.00 & & & & \\
\hline $\mathrm{KP} 3 \longleftarrow \mathrm{KP}$ & 1.149 & .386 & 2.978 & 0.03 & Par_1 \\
\hline $\mathrm{KP} 2 \longleftarrow \mathrm{KP}$ & 1.189 & .358 & 3.320 &.$* * *$ & Par_2 \\
\hline $\mathrm{KP} 1 \longleftarrow \mathrm{KP}$ & .944 & .309 & 3.056 & .002 & Par_3 \\
\hline
\end{tabular}

Berdasarkan hasil pengujian seperti terlihat dalam Gambar 8. dan Tabel 5., koefisien masing-masing indikator peubah persepsi harga memiliki loading factor $>0.40$ pada diagram path dan untuk mengetahui kuatnya dimensi yang membentuk faktor latent dapat dilihat dari bobot faktor, yang dapat dianalisis dengan menggunakan uji-t identik dengan nilai Critical ratio (CR), di mana indikator memilki nilai $\mathrm{CR}>2.0$

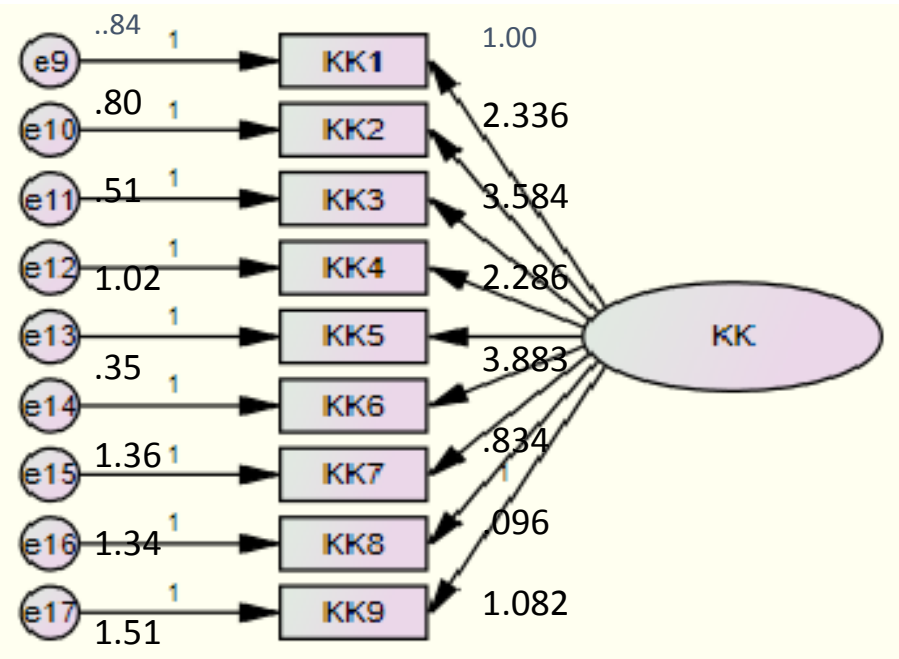

1.03

Gambar 9. Analisis Faktor Konfirmatori Peubah Kepuasan Konsumen Sumber : Olah data AMOS 22, 2016 
Tabel 6. Regression Weights (Peubah Kepuasan Konsumen)

\begin{tabular}{|c|c|c|c|c|c|c|}
\hline & & Estimate & S.E & C.R. & $\mathrm{P}$ & Label \\
\hline KK1 & $\longleftarrow \mathrm{KK}$ & 1.00 & & & & \\
\hline KK2 & $\longleftarrow \mathrm{KK}$ & 2.336 & .797 & 2.931 & .003 & Par_1 \\
\hline KK3 & $\longleftarrow \mathrm{KK}$ & 3.584 & 1.175 & 3.050 & .002 & Par 2 \\
\hline KK4 & $\longleftarrow \mathrm{KK}$ & 2.286 & .800 & 2.857 & .004 & Par_3 \\
\hline KK5 & $\longleftarrow \mathrm{KK}$ & 3.883 & 1.282 & 3.029 & .002 & Par_4 \\
\hline KK6 & $\longleftarrow \mathrm{KK}$ & .834 & .477 & 1.747 & .081 & Par 5 \\
\hline KK 7 & $\longleftarrow \mathrm{KK}$ & .096 & .400 & .241 & .810 & Par 6 \\
\hline KK8 & $\longleftarrow \mathrm{KK}$ & 1.082 & .538 & 2.012 & .044 & Par_7 \\
\hline KK9 & $\longleftarrow \mathrm{KK}$ & .604 & .390 & 1.549 & .121 & Par_8 \\
\hline
\end{tabular}

Berdasarkan hasil pengujian seperti terlihat dalam Gambar 9. dan Tabel 6., koefisien masing-masing indikator peubah kepuasan konsumen memiliki loading factor $>0.40$ pada diagram path kecuali KK7, dan untuk mengetahui kuatnya dimensi yang membentuk faktor latent dapat dilihat dari bobot faktor, yang dapat dianalisis dengan menggunakan uji-t identik dengan nilai Critical ratio (CR), di mana indikator memilki nilai $\mathrm{CR}>2.0$, kecuali $\mathrm{KK} 7$ dan KK9.

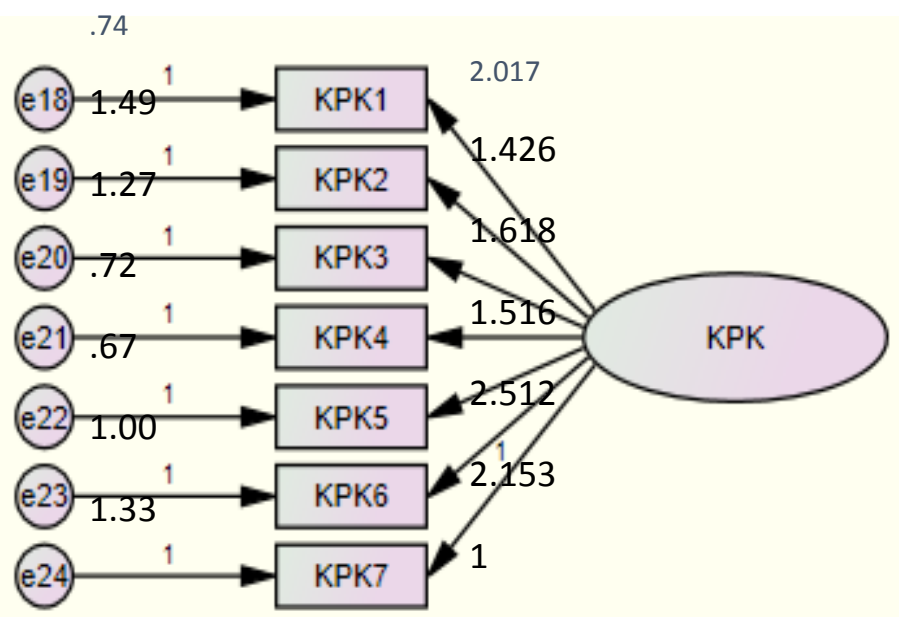

Gambar 10. Analisis Faktor Konfirmatori Peubah Kepuasan Konsumen Sumber : Olah data AMOS 22, 20

Tabel 7. Regression Weights (Peubah Kepuasan Konsumen)

\begin{tabular}{|l|l|l|l|l|l|}
\hline & Estimate & S.E & C.R. & P & Label \\
\hline KPK1 KPK & 1.00 & & & & \\
KPK2 KPK & 2.153 & .973 & 2.212 & .027 & Par_1 \\
KPK3 KPK & 2.512 & 1.092 & 2.299 & .021 & Par_2 \\
KPK4 KPK & 1.516 & .734 & 2.066 & .039 & Par_3 \\
KPK5 KPK & 1.618 & .844 & 1.918 & .055 & Par_4 \\
KPK6 KPK & 1.426 & .788 & 1.808 & .071 & Par_5 \\
KPK7 KPK & 2.017 & .974 & 2.07 & .038 & Par_6 \\
\hline
\end{tabular}


Berdasarkan hasil pengujian seperti terlihat dalam Gambar 10. dan Tabel 7., koefisien masing-masing indikator peubah kepuasan konsumen memiliki loading factor $>0.40$, dan untuk mengetahui kuatnya dimensi yang membentuk faktor laten dapat dilihat dari bobot faktor, yang dapat dianalisis dengan menggunakan uji-t identik dengan nilai Critical ratio (CR), di mana indikator memiliki nilai $\mathrm{CR}>2.0$, kecuali KPK5 dan KPK6.

\section{Analisis Structural Equation Modeling (SEM) \\ Pengujian terhadap kesesuaian model dilakukan melalui telaah terhadap berbagai kriteria goodness of fit. Hasil pengujian kelayakan model penelitian SEM dapat dilihat pada tabel berikut:}

Tabel 8. Hasil Pengujian Kelayakan Full Model Penelitian SEM

\begin{tabular}{|l|c|c|c|}
\hline Goodness of Fit Index & Cut-off Value & Hasil & Evaluasi \\
\hline Probability & $>0.05$ & 0.095 & Kecocokan baik \\
\hline CMIN/DF & $\leq 2.00$ & 0.741 & Kecocokan baik \\
\hline GFI & $\geq 0.9$ & 0.946 & Kecocokan baik \\
\hline AGFI & $\geq 0.9$ & 0.920 & Kecocokan baik \\
\hline TLI & $\geq 0.9$ & 0.981 & Kecocokan baik \\
\hline RMSEA & $\leq 0.08$ & 0.000 & Kecocokan baik \\
\hline CFI & $\geq 0.9$ & 0.909 & Kecocokan baik \\
\hline
\end{tabular}

Berdasarkan Tabel 8., hasil pengujian kelayakan model keseluruhan SEM menyimpulkan bahwa indeks Probability, CMIN/DF, GFI, AGFI, TLI, RMSEA, CFI menghasilkan kecocokan yang baik, sehingga model keseluruhan SEM dapat diteruskan ke pengujian hipotesis tanpa melakukan respesifikasi atau modifikasi.

\section{Hasil Pengujian Hipotesis}

Uji hipotesis ini dibuat berdasarkan hasil pengolahan data dan analisis SEM, di mana hasil Regression Weights Analysis dicermati dengan cara melihat nilai Standardized Coefficient (Estimate of Standardized RegressionWeights), Critical Ratio (C.R.) dan nilai Probability (P), dibandingkan dengan kriteria statistik yang ditentukan, yaitu C.R. > 1,96 dengan P < 0,05 . Hipotesis yang diajukan dikatakan punya pengaruh signifikan apabila olah data menunjukkan hasil yang memenuhi kriteria C.R. $>1,96$ dengan $P<0,05$. Hasil analisis SEM ditunjukkan pada Tabel 9.

Tabel 9. Hasil Analisis SEM

\begin{tabular}{|c|l|l|l|l|l|}
\hline Hipotesis & Path & Estimasi & CR & P & Kesimpulan \\
\hline $\mathrm{H} 1$ & $\begin{array}{l}\text { Persepsi Harga } \longrightarrow \\
\text { Kepuasan Konsumen }\end{array}$ & 0.5146 & 4.589 & .000 & $\begin{array}{l}\text { Mendukung } \\
\text { hipotesis }\end{array}$ \\
\hline $\mathrm{H} 2$ & $\begin{array}{l}\text { Persepsi Harga } \\
\text { Keputusan Pembelian }\end{array}$ & 0.123 & 1.225 & 0.221 & $\begin{array}{l}\text { Tidak mendukung } \\
\text { hipotesis }\end{array}$ \\
\hline $\mathrm{H} 3$ & $\begin{array}{l}\text { Kualitas produk } \\
\text { Kepuasan Konsumen }\end{array}$ & 0.453 & 4.14 & 0.00 & $\begin{array}{l}\text { Mendukung } \\
\text { hipotesis }\end{array}$ \\
\hline $\mathrm{H} 4$ & $\begin{array}{l}\text { Kualitas produk } \\
\text { Keputusan Pembelian }\end{array}$ & 0.064 & 0.511 & 0.619 & $\begin{array}{l}\text { Tidak mendukung } \\
\text { hipotesis }\end{array}$ \\
\hline $\mathrm{H} 5$ & $\begin{array}{l}\text { Kepuasan konsumen } \\
\text { Keputusan Pembelian }\end{array}$ & 0.863 & 4.414 & 0.00 & $\begin{array}{l}\text { Mendukung } \\
\text { hipotesis }\end{array}$ \\
\hline
\end{tabular}


Hasil SEM seperti terlihat pada Tabel 9. dapat diinterpretasi sebagai berikut :

1. Pengujian tentang pengaruh persepsi harga terhadap kepuasan konsumen dengan hipotesis penelitian (H1).

H1 : Persepsi Harga berpengaruh positip terhadap Kepuasan Konsumen.

Pada kolom $\mathrm{P}$ pada pengujian persepsi harga terhadap kepuasan konsumen adalah 0,00 $(<0.05)$, dan kolom CR nilainya adalah 4.586 (>1.96), maka hipotesis 1 diterima, penelitian ini secara signifikan mendukung pernyataan bahwa persepsi harga berpengaruh positif terhadap kepuasan konsumen

2. Pengujian tentang pengaruh persepsi harga terhadap keputusan pembelian dengan hipotesis penelitian (H2) sebagai berikut :

H2 : Persepsi Harga berpengaruh positip terhadap Keputusan Pembelian

Pada kolom $\mathrm{P}$ pada pengujian persepsi harga terhadap kepuasan konsumen adalah 0,221(>0.05), dan kolom CR nilainya adalah $1.225(<1.96)$, maka hipotesis 2 ditolak, penelitian ini tidak secara signifikan mendukung pernyataan bahwa persepsi harga berpengaruh positif terhadap keputusan pembelian

3. Pengujian tentang pengaruh kualitas produk terhadap kepuasan konsumen dengan hipotesis penelitian (H3) sebagai berikut :

H3 : Kualitas Produk berpengaruh positip terhadap Kepuasan Konsumen Pada kolom P pada pengujian kualitas produk terhadap kepuasan konsumen adalah 0,00 atau $<0.05$, dan kolom $\mathrm{CR}$ nilainya adalah 4.14 atau $>1.96$, maka hipotesis 3 diterima, penelitian ini secara signifikan mendukung pernyataan bahwa kualitas produk berpengaruh positif terhadap kepuasan konsumen

4. Pengujian tentang pengaruh kualitas produk terhadap keputusan pembelian dengan hipotesis penelitian (H4) sebagai berikut :

H4 : Kualitas Produk berpengaruh positip terhadap Keputusan Pembelian Pada kolom P pada pengujian persepsi harga terhadap kepuasan konsumen adalah 0,619 (>0.05), dan kolom CR nilainya adalah $0.511(<1.96)$, maka hipotesis 4 ditolak, penelitian ini tidak secara signifikan mendukung pernyataan bahwa persepsi harga berpengaruh positif terhadap keputusan pembelian.

5. Pengujian tentang pengaruh kepuasan konsumen terhadap keputusan pembelian dengan hipotesis penelitian (H5) sebagai berikut :

H5 : Kepuasan Konsumen berpengaruh positip terhadap Keputusan Pembelian

Pada kolom P pada pengujian persepsi harga terhadap kepuasan konsumen adalah 0,00 atau $<0.05$, dan kolom $\mathrm{CR}$ nilainya adalah 4.414(>1.96), maka hipotesis 5 diterima, penelitian ini secara signifikan mendukung pernyataan bahwa persepsi harga berpengaruh positif terhadap kepuasan konsumen 
Analisis Pengaruh

Pengaruh langsung

Tabel 10. Hasil Analisis SEM Pengaruh Langsung.

\begin{tabular}{|l|l|l|l|l|}
\hline & Persepsi harga & $\begin{array}{l}\text { Kualitas } \\
\text { Produk }\end{array}$ & $\begin{array}{l}\text { Kepuasan } \\
\text { konsumen }\end{array}$ & $\begin{array}{l}\text { Keputusan } \\
\text { Pembelian }\end{array}$ \\
\hline $\begin{array}{l}\text { Kepuasan } \\
\text { Konsumen }\end{array}$ & 0,525 & 0,452 & 0 & 0 \\
\hline $\begin{array}{l}\text { Keputusan } \\
\text { pembelian }\end{array}$ & $-0,017$ & $-0,105$ & 0,889 & 0 \\
\hline
\end{tabular}

Berdasarkan Tabel 10 menunjukkan bahwa pengaruh langsung persepsi harga terhadap keputusan pembelian konsumen sebesar $-0,17$. Pengaruh langsung persepsi harga terhadap kepuasan konsumen sebesar 0,525 . Pengaruh langsung kualitas terhadap keputusan pembelian konsumen sebesar 0,105 . Pengaruh langsung kualitas terhadap kepuasan konsumen sebesar 0,452. Pengaruh langsung kepuasan konsumen terhadap keputusan pembelian konsumen sebesar 0,889 .

\section{Pengaruh Tidak Langsung}

Tabel 11. Hasil Analisis SEM Pengaruh Tidak Lansung

Sumber : (Hasil Olahan, 2016)

\begin{tabular}{|l|l|l|l|l|}
\hline & Persepsi harga & Kualitas Produk & $\begin{array}{l}\text { Kepuasan } \\
\text { konsumen }\end{array}$ & $\begin{array}{l}\text { Keputusan } \\
\text { Pembelian }\end{array}$ \\
\hline $\begin{array}{l}\text { Kepuasan } \\
\text { Konsumen }\end{array}$ & 0 & 0 & 0 & 0 \\
\hline $\begin{array}{l}\text { Keputusan } \\
\text { pembelian }\end{array}$ & 0,466 & 0,402 & 0 & 0 \\
\hline
\end{tabular}

Berdasarkan Tabel 11. dapat diketahui bahwa, pengaruh tidak langsung persepsi harga terhadap keputusan pembelian konsumen sebesar 0,466 dan pengaruh tidak langsung kualitas produk terhadap keputusan pembelian konsumen sebesar 0,402.

\section{Pengaruh Total}

Tabel 12. Hasil Analisis SEM Pengaruh Total

Sumber : (Hasil Olahan, 2016)

\begin{tabular}{|l|l|l|l|l|}
\hline & Persepsi harga & Kualitas Produk & $\begin{array}{l}\text { Kepuasan } \\
\text { konsumen }\end{array}$ & $\begin{array}{l}\text { Keputusan } \\
\text { Pembelian }\end{array}$ \\
\hline $\begin{array}{l}\text { Kepuasan } \\
\text { Konsumen }\end{array}$ & 0,525 & 0,452 & 0 & 0 \\
\hline $\begin{array}{l}\text { Keputusan } \\
\text { pembelian }\end{array}$ & 0,337 & 0,296 & 0,889 & 0 \\
\hline
\end{tabular}

Berdasarkan Tabel 12. diketahui bahwa pengaruh total persepsi harga terhadap keputusan pembelian konsumen sebesar 0,337 . Pengaruh total persepsi harga terhadap kepuasan konsumen sebesar 0,525. Pengaruh total kualitas produk terhadap keputusan pembelian konsumen sebesar 0,296 . Pengaruh total kualitas produk terhadap kepuasan konsumen sebesar 0,452.
Pengaruh total kepuasan konsumen terhadap keputusan pembelian sebesar 0,889.

\section{Pembahasan}

Hasil pengujian model pengukuran dalam penelitian ini menunjukkan bahwa seluruh peubah telah memenuhi kriteria kesahihan dan keandalan, begitu juga dengan hasil pengujian kelayakan model 
keseluruhan SEM menunjukkan bahwa indeks goodness of fit menghasilkan kecocokan yang baik. Hasil pengujian hipotesis bahwa persepsi harga berpengaruh secara positif dan signifikan terhadap kepuasan konsumen Indomaret Rorotan Jakarta Utara, terbukti dengan nilai C.R sebesar 4.589 dan P sebesar 0,00. Hal ini mengandung pengertian bahwa kepuasan konsumen timbul karena konsumen mempersepsikan harga sebuah produk sebagai produk yang bermanfaat bagi dirinya, baik dari segi kualitas produk, kualitas pelayanan dan suasana dan fasilitas yang ada di mini market Indomaret. Dengan demikian hasil penelitian ini mendukung teori dan penelitian dari Zeithami (1988) dan Hermann et al. (2007) yang menyatakan persepsi harga berpengaruh secara positif dan signifikan terhadap kepuasan konsumen.

Selanjutnya hasil penelitian ini menunjukkan bahwa persepsi harga tidak berpengaruh secara positif dan signifikan terhadap keputusan pembelian konsumen Indomaret Rorotan, Jakarta Utara, terbukti dengan nilai C.R sebesar 1,225 dan $P$ sebesar 0,221 Dengan demikian hasil penelitian ini tidak mendukung penelitian dari Tan (2011) dan Owusu Alfred (2013) yang menyatakan bahwa persepsi harga memiliki pengaruh positif dan signifikan terhadap keputusan pembelian konsumen.

Hasil penelitian ini juga menunjukkan bahwa kualitas produk berpengaruh positif dan signifikan terhadap kepuasan konsumen, terbukti dengan nilai CR sebesa 4.14 dan P sebesar 0,00. Dengan demikian hasil penelitian ini mendukung hasil penelitian yang dilakukan oleh Suci Widyawati et al. (2012), menyatakan bahwa kualitas produk, harga, dan nilai pelanggan berpengaruh signifikan terhadap kepuasan pelanggan

Hasil penelitian ini juga
menunjukkan bahwa kualitas produk tidak berpengaruh secara positif dan signifikan terhadap keputusan pembelian konsumen Indomaret Rorotan,Jakarta Utara, terbukti dengan nilai C.R sebesar 0,511 dan P sebesar 0,619. Dengan demikian hasil penelitian ini tidak mendukung teori dan penelitian dari Rajput et al. (2012) dan Owusu Afred (2013) yang menyatakan bahwa persepsi kualitas produk memiliki pengaruh positif dan signifikan terhadap keputusan pembelian konsumen.

Pengujian hipotesis terakhir, hasil penelitian ini menunjukkan bahwa kepuasan konsumen berpengaruh secara positif dan signifikan terhadap keputusan pembelian konsumen Indomaret Rorotan, Jakarta Utara, terbukti dengan nilai C.R sebesar 4,414 dan $\mathrm{P}$ sebesar 0,00. Beberapa indikator yang dominan berpengaruh terhadap kepuasan konsumen, adalah penguasaan seluk beluk mini market, keramahan karyawan, alternatif barang sejenis , keterampilan layanan, dan keamanan berbelanja. Dengan demikian hasil penelitian ini mendukung teori dan penelitian dari Bei dan Chiao (2001) dan Elfri et. Al (2014) yang menyatakan bahwa persepsi kualitas produk memiliki pengaruh positif dan signifikan terhadap keputusan pembelian konsumen.

Analisis pengaruh langsung, tidak langsung dan pengaruh total menunjukkan bahwa pengaruh lansung dari persepsi harga terhadap keputusan pembelian menunjukkan hasil yang lebih kecil dibandingkan dengan pengaruh tidak lngsung sehingga efek mediasi peubah kepuasan konsumen berpengaruh terhadap keputusan pembelian. Begitu juga pengaruh lansung kualitas produk terhadap keputusan pembelian lebih kecil dari pengaruh tidak langsung, sehingga peubah kepuasan konsumen memiliki efek mediasi terhadap keputusan pembelian.

\section{SIMPULAN DAN SARAN}

1. Keputusan pembelian konsumen tidak dipengaruhi secara signifikan dan positif oleh persepsi harga sehingga hipotesis-2 ditolak, artinya keputusan pembelian konsumen tidak akan meningkat apabila kepuasan konsumen meningkat. Dengan demikian hasil penelitian ini tidak mendukung hasil penelitian dari Tan (2011) dan Owusu Alfred (2013).

2. Keputusan pembelian konsumen tidak dipengaruh secara positif dan signifikan oleh kualitas produk dengan demikian hipotesis-4 ditolak, artinya keputusan pembelian tidak akan meningkat apabila kualitas produk ditingkatkan. Hasil penelitian ini tidak mendukung 
hasil penelitian Rajput (2012) dan Owusu Alfred (2013).

3. Keputusan pembelian konsumen secara positif dan signifikan dipengaruhi oleh kepuasan konsumen. Dengan demikian hipotesis-5 diterima, artinya keputusan pembelian akan meningkat apabila kepuasan konsumen ditingkatkan. Peubah kepuasan konsumen dideterminasi oleh jaminan kualitas produk, alternatif barang sejenis, keramahan pelayanan, keterampilan layanan, menguasai seluk beluk mini market, banyaknya fasilitas, keamanan, dan kebersihan di mana kedelapan faktor ini memiliki loading factor yang tinggi atau lebih besar dari 0.4. Hasil penelitian ini mendukung hasil penelitian yang dilakukan oleh Bei dan Chiao (2001 dan Elfri et al. (2014),

4. Kepuasan konsumen dipengaruhi secara signifikan dan positip oleh persepsi harga sehingga hipotesis 1 diterima, artinya kepuasan konsumen akan meningkat apabila persepsi harga ditingkatkan. Peubah persepsi harga dideterminasi oleh indikator kesesuaian harga dengan kualitas, keterjangkauan harga, daya beli konsumen, dan pengambilan keputusan konsumen, di mana keempat indikator tersebut memiliki loading factor yang tinggi atau lebih besar dari 0.4. Hasil penelitian ini mendukung hasil penelitian dari Zeithami (1988) dan Hermann et al. (2007).

5. Kepuasan konsumen dipengaruhi secara signifikan dan positip oleh kualitas produk sehingga hipotesis -3 diterima, artinya kepuasan konsumen akan meningkat apabila kualitas produk ditingkatkan. Peubah kualitas produk dideterminasi oleh kemudahan penggunaan, kejelasan fungsi, keragaman ukuran produk, dan daya tahan di mana keempat indikator memiliki loading factor yang tinggi atau lebih besar dari 0.4. Hasil penelitian ini mendukung hasil yang dilakukan oleh Suci Widyawati et al. (2012)
6. Peubah intervening Kepuasan konsumen memiliki pengaruh terhadap keputusan pembelian untuk memediasi peubah persepsi harga dan kualitas produk.

\section{SARAN}

Berdasarkan hasil penelitian ini, penulis memberikan saran sebagai berikut :

1. Akademis

Peubah bebas yang memengaruhi peubah gayut keputusan pembelian dapat diperluas lagi selain persepsi harga, kualitas produk, dan kepuasan konsumen.

2. Praktis

a) Bagi manajemen, keputusan pembelian dapat dibangun dengan meningkatkan kualitas produk, melalui peningkatan kemudahan penggunaan, kejelasan fungsi, keragaman ukuran produk, dan daya tahan

b) Keputusan pembelian juga dapat dibangun dengan meningkatkan kepuasan konsumen melalui peningkatan jaminan kualitas produk, alternatif barang sejenis, keramahan pelayanan, keterampilan layanan, menguasai seluk beluk mini market, banyaknya fasilitas, keamanan, dan kebersihan.

c) Kepuasan konsumen merupakan keinginan yang ingin dicapai oleh perusahaan dalam rangka meningkatkan keuntungan. Dalam memenuhi kepuasan konsumen perusahaan perlu meningkatkan persepsi harga melalui peningkatan kesesuaian harga dengan kualitas, keterjangkauan harga, daya beli konsumen, dan pengambilan keputusan konsumen.

\section{Keterbatasan Penelitian}

Penelitian ini hanya dilakukan pada satu Indomaret yang berlokasi di Rorotan Jakarta Utara, maka penelitian berikutnya diharapkan dapat meningkatkan ruang lingkup penelitian dengan subjek penelitian 
yang lebih banyak seperti kelurahan, kecamatan, atau provinsi, bahkan dengan mebandingkan dengan retail lainnya seperti Alfamart.

Peubah yang digunakan pada penelitian ini hanya mencakup peubah persepsi harga, kualitas produk dan kepuasan konsumen, penelitian selanjutnya dapat menambahkan peubah lain yang berpengaruh terhadap keputusan pembelian konsumen, seperti promosi, citra merek, kualitas layanan, dan lain-lain. Selain itu indikator-indikator penelitian yang digunakan dalam penelitian ini dapat ditambah dengan indikator-indikator lain di luar penelitian ini yang relevan dengan penelitian yang akan dilakukan di masa mendatang.

\section{DAFTAR PUSTAKA}

.Amir, M. Taufiq. 2005. Dinamika Pemasaran: Jelajahi \& Rasakan. Jakarta: PT. RajaGrafindo Persada. Ariestonandri, Prima.

Arikunto, Suharsimi. 2006. Prosedur Penelitian Suatu Pendekatan Praktik. Jakarta: PT. Rineka Cipta.

Assauri, Sofjan. 2012. Manajemen Pemasaran. Cetakan Kesepuluh. Rajawali Pers. Jakarta.

Bei, L.T. and Chiao, Y.C. 2001, An integrated model for the effects of perceived product, perceived service quality, and perceived price fairness on consumer satisfaction and loyalty, Journal of Consumer Satisfaction, Dissatisfactionand Complaining Behavior.

Boone, Louis e. dan Kurtz, David. 2007. Pengantar Bisnis Kontemporer. Edisi sebelas. Jakarta: Selemba Empat.

Elfri Ngutji, Altje Tumbel dan Jopie J Rotinsulu, 2014. Kualitas Pelayanan dan Kepuasan konsumen Pengaruhnya Terhadap Kesetiaan merek Fried Chicken (KFC) Megamall Manado, Jurnal EMBA Vol.2 No.1

Erwin Rediono Tan (2011). Pengaruh faktor harga, promosi dan pelayanan terhadap keputusan konsumen untuk belanja di alfamart surabaya. Jurnal Kewirausahaan Volume 5 Nomor 2 ISSN. 1978-4724

Ferdinand, Agusty, 2002, "Structural Equation Modelling dalam Penelitian Manajemen", Badan Penerbit Universitas Diponegoro, Semarang.

Gasperz, Vincent. 2005. Total Quality Management. Jakarta : PT. Gramedia Pustaka Utama.

Gerson, F Richard. 2002. Mengukur Kepuasan Pelanggan. Jakarta : PPM.

Ghozali, Imam, 2005, Aplikasi Analisis Multivariate dengan Program SPSS,

Hawkins, D.I., R.J, Best, and K.A. Coney, 1986, Consumer Behavior, Texas, Business Publication.

Herliyanah 2008. " Analisis hubungan antara faktor harga, kualitas, kesediaan produk,dan Merek

Hermann et al. 2007. "The Influence of Price Fairness on Customer Satisfaction: An Empirical Test in The Context of Automobile Purchases". Journal of Product \& Brand Management. Vol.16, No.1, pp 49-58.

Irawan , Handi, 2009, Sepuluh Prinsip Kepuasan Pelanggan, Penerbit Elex

Kotler Philip. 2006, Marketing Management Millenium, Edition Prentice Hall International New Jersey.

Kotler Philiph and Keller, 2009, Marketing : An Introduction, Fourth Ed, Prentice Hall, Canada.

Kotler, Philip dan Amstrong Gery. 2004. Prinsip-prinsip Pemasaran. Jakarta: PT.Malanan Jaya Cermelang.7

Kurniawan. 2010. Management Marketing. Journal of A Case Study in Air Asia,

Lonardo dan Yasintha Soelasih, 2014, Analisis Pengaruh Kualitas Produk, Harga, dan Lingkungan Fisik.Jurnal Manajemen .vol 1 no. 1

Ma'ruf, Hendri. 2005. Pemasaran Ritel. Jakarta: Gramedia Pustaka Utama. 
Malhotra, Naresh K. 2009. Riset Pemasaran Pendekatan Terapan. Edisi keempat. Jilid 2. PT. Indeks Kelompok Gramedia

Nadia Rizqiyatul Faizah, Sri Suryoko \& Saryadi,2014. Pengaruh Harga, Kualitas Produk dan Kualitas Pelayanan Terhadap Kepuasan Pelanggan O-Mamamia Steak And Ice Cream Cabang Jati Semarang, Diponegoro Journal of Social And Politic.

Nugroho. 2003, Perilaku Konsumen Konsep dan Implikasi untuk Strategi dan Penelitian Pemasaran. Jakarta .

Oliver, 2007. Measurement and Evaluation of Satisfaction Processes in Retail Settings. Journal of Retailing. 57(3), 25-48.

Owusu Alfred, 2013 . Influences of Price And Quality On Consumer Purchase Of Mobile Phone In The Kumasi Metropolis In Ghana A Comparative Study, European Journal of Business and Management, Vol.5, No.1.

Pardede R., dan Manurung R.,2014. Analisis Jalur (Path Analysis) : Teori dan Aplikasi Dalam Riset Bisnis, Penerbit Rineka Cipta Jakarta

Rajput, A.A.; Kalhoro, S.H.; dan Wasif, R. 2012. Impact of Product Price and Quality on Consumer Buying Behavior: Evidence from Pakistan. Interdisciplinary Journal of Contemporary Research In Business. ijcrb.webs.com. Vol 4, No 4. August, h.585-496.

Rangkuti, Fredly. 2006. Messuring Customer Satisfaction. Jakarta : PT. Gramedia Pustaka Utama.

Richard F, Gerson. 2001. Mengukur Kepuasan Pelanggan, Panduan Menciptakan Pelayanan Bermutu. Crips Publications.
Rui Wang dan Brian Hempton, John P. Dugan dan Susan R. Komives, 2008. Cultural Differences: Why Do Asians Avoid Extreme Responses. Journal Intenational American Association for Public Opinion Reseach, Vol. 1. No.3

Saladin Djaslim. 2006. Unsur-unsur Inti Pemasaran dan Manajemen Pemasaran. Bandung: Mandar Maju

Sarini Kodu, 2013. Harga, Kualitas Produk dan kualitas Pelayanan Pengaruhnya Terhadap Keputusan Pembelian Mobil Toyota Avanza, Jurnal EMBA 1251 Vol.1 No.3

Suci Widyawati1, Naili Farida2 \& Andi Wijayanto3 Sudarwanto. Tri. "Pengaruh Strategi promosi Midnight sale terhadap keputusan pembelian" sudutpandang Asia. Indeks . Jakarta 2005

Sutisna. 2003. Perilaku Konsumen dan Komunikasi Pemasaran. Bandung: PT. Remaja Rosdakarya.

Tambunan, Tulus TH., 2004. Kajian Persaingan dalam Industri Retail. Komisi Pengawas Persaingan Usaha (KPPU).

Tjiptono, Fandy. 2004. Perspektif Manajemen dan Pemasaran Kontemporer. Yogyakarta : Andi.

Veloutsou, 2005. Determinants of Customer Satisfaction in Fast Food Industry. Journal of Management Strategy, Vol. No. 3

Wijayanti, A., 2008. Strategi Meningkatkan Loyalitas melalui Kepuasan Pelanggan, thesis Universitas Diponegoro, Semarang.

Zeithaml, Valarie A. 2002. Consumer Perception of Price, Quality, and Value: "A Means End Model And Synthesis of Evidence", Journal of Marketing, Vol.52 